\title{
Comparative Economical Analysis of the Treatment Adopted for Canine Parvo Virus Infected Dog
}

\author{
Sudhir Mehta ${ }^{1 *}$, Suresh Mavadiya ${ }^{1}$, Saurabh Parmar ${ }^{2}$, Arshi Vagh ${ }^{3}$, Jignesh Vala² and Ramesh Patel ${ }^{4}$ \\ ${ }^{1}$ Department of Veterinary Medicine, Veterinary College, NAU, Navsari, Gujarat, INDIA \\ ${ }^{2}$ Department of Veterinary Clinical Complex, Veterinary College, NAU, Navsari, Gujarat, INDIA \\ ${ }^{3}$ Department of Veterinary Medicine, Veterinary College, JAU, Junagadh, Gujarat, INDIA \\ ${ }^{4}$ Department Veterinary Clinical Complex, Veterinary College, SDAU, Sadarkrushinagar, Gujarat, INDIA \\ *Corresponding author: S Mehta; E-mail: drsudhiram7@gmail.com
}

Received: 07 May, 2020

Revised: 25 Aug., 2020

Accepted: 04 Sept., 2020

\begin{abstract}
In the present study, 50 dogs screened using Scan Vet Parvo rapid diagnostic kit for canine parvovirus (CPV) Infection and 34 (68\%) found positive among them. Out of $34 \mathrm{CPV}$-positive dogs, 28 dogs were randomly divided in four different treatment groups for determining the efficacy of treatments along with its economies. The groups I, II, III and IV dogs were treated with antimicrobial agent Inj. Cefotaxim, Metronidazole, acyclovir and Inj. Cefotaxim + Acyclovir, respectively with similar supportive drugs in all the groups for five days. The case fatality rate was recorded $0 \%$ in group I and IV whereas it was $57.14 \%$ and $42.85 \%$ in groups III and II. Based on statistics, it was found that the treatment with cefotaxim alone was found more economical and equally efficient besides the combined use of cefotaxim + Acyclovir but combine treatment could also be hasten the recovery from the $\mathrm{CPV}$ infection.
\end{abstract}

\section{HIGHLIGHTS}

( Cefotaxim is efficient and economical choice of antibiotic for CPV infection.

(0 Acyclovir must be used in combination with any sensitive antibiotic in the case of CPV infection.

Keywords: Canine parvovirus, dogs, economical

Canine parvo virus is an important pathogen of domestic and wild canines and has spread worldwide since its emergence in 1977. There are two different parvo viruses known to infect dogs - the pathogenic CPV-2 and CPV1 or the Canine Minute Virus (CnMV). Season-wise incidence showed that cases were almost exclusively occurred in winter followed by monsoon (Pandya et al., 2017). Host associated risk factors like age, sex,breed, vaccination and seasons responsible for occurrence of canine parvo virus infection (Sharma et al., 2019). The disease is clinically represent in two prominent forms, enteritis with vomition and diarrhea in dogs of all ages and myocarditis and subsequent heart failure in pups of less than 3 months of age with high morbidity and frequent mortality $10 \%$ in adult dogs and $91 \%$ in pups
(Nandi and Manojkumar, 2010). The virus kills one of two ways, diarrhea and vomiting lead to extreme fluid loss and dehydration until shock and resulted in death and loss of the intestinal barrier allows bacterial invasion of potentially the entire body. The survival rate of CPV infection is as low as $9.1 \%$ in the absence of treatment and $64 \%$ or higher with treatment because of no agentspecific treatment exists for CPV enteritis, management of clinical signs remains supportive care (Otto et al., 2010). Since there was no earlier report on economical estimation

How to cite this article: Mehta, S., Mavadiya, S., Parmar, S., Vagh, A., Vala, J. and Patel, R. (2020). Comparative economical analysis of the treatment adopted for canine parvo virus infected dog. J. Anim. Res. 10(5): 843-848.

Source of Support: None; Conflict of Interest: None 
of treatment cost of CPV infection, the present study was under taken.

\section{MATERIALS AND METHODS}

The study was carried out on dogs presented at the Teaching Veterinary Clinical Complex, College of Veterinary Science, NAU, Navsari. A total of 50 dogs showing probable clinical signs like diarrhea with/without blood, vomition, anorexia, anemic and dehydrated due to vomition/diarrhea were selected and screened through Scan Vet Parvo (rapid faecalparvo Ag detection kit). The aseptically collected faecal swabs from suspected cases were put into a sample tube containing $2 \mathrm{ml}$ of buffer. The buffer with swab was swirled and four drops of liquid were put into the specimen well (S). The test results were read within 5-10 minutes. One red-purple band appears in the control line with no apparent band in the test line (T) considered as negative sample (Fig. 1) and two red-purple bands appear one in the control line (C) and other in the test line (T) noted as positive sample (Fig. 1).

Out of 50, 34 dogs found positive through ScanVetParvo and among them 28 dogs were randomly divided in four treatment groups $(n=7)$. The detailed history, clinical scores, hematological parameters, treatment administered and its cost were recorded of each dog of all the groups. The group wise treatments adopted for aforesaid dogs were mentioned in table 1.

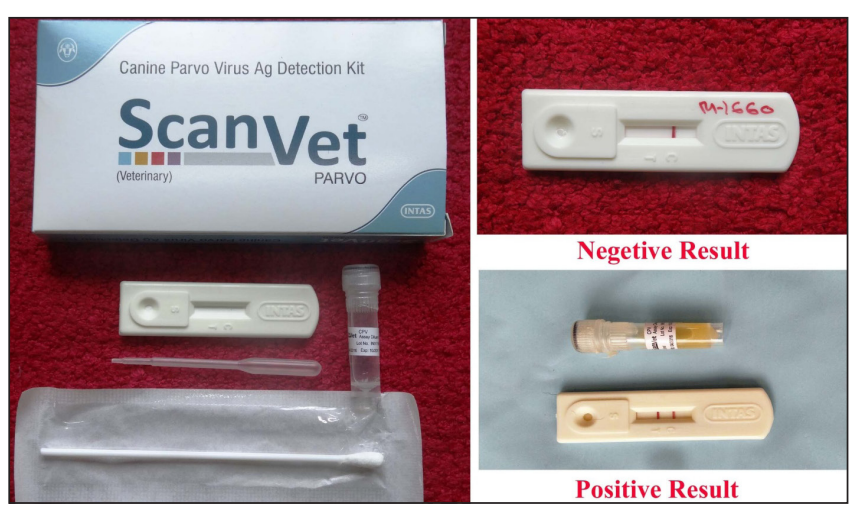

Fig. 1: Canine Parvo Virus test kit along with interpretation of results

The clinical score of CPV affected dogs were determined through method suggested by Mohr et al. (2003) (Table 2 ). The Score of each category was assigned to each dog twice daily to encompass the previous 12 hours period and score was decided on the basis of majority in three clinical attributes.

\section{STATISTICAL ANALYSIS}

The data of clinical score of day 0 and day 5 were analyzed by paired $t$ test and one way ANOVA for independent variance used to determine the efficacy and economics of treatment adopted for various groups as per method suggested by Snedecor and Cochran (1990).

\section{RESULTS AND DISCUSSION}

The groups were continually monitored from day 1 to day 5 and clinical scoring recorded in clinical attributes of each patient: attitude, appetite, vomiting, temperature and feces. A score of 0 represented a clinically normal parameter, with increasing severity of signs as the score increased up to a maximum of 3 for each variable.

It was observed in the study that dogs pertaining to group I to IV were presented with severe depression, not interested in food by themselves, moderate vomiting in which dogs voided yellowish to greenish color vomitus 2-5 times in $12 \mathrm{hrs}$ interval, rectal temperature of dogs was around $102.23 \pm 1.92{ }^{\circ} \mathrm{F}$ and feaces of all the dogs were diarrheic with or without blood on the day of admission i.e. day 1 . The clinical score of day 2 were remain constant in group I, II and III as on day 1 but the score decreased from $2.43 \pm 0.20$ to $1.57 \pm 0.20$ in group IV indicated improvement in clinical condition due to effectiveness of treatment received in that particular group. The clinical score reached to 0 of group IV $(0.86 \pm 0.26)$ on day 3 onwards, group I on day 4 onwards and group II and III on day $5^{\text {th }}$. The case fatality rate was $57.14 \%$ and $42.85 \%$ in group III and II. The clinical efficacy in group I, II, III and IV were $100.00 \%(7 / 7), 57.14 \%(4 / 7), 42.85 \%(3 / 7)$ and $100.00 \%(7 / 7)$ in terms of survivability from CPV affected animals. The clinical score 0 suggestive of either of three presents; normal attitude, appetite, no vomition, well formed feces and temperature in normal reference range of particular group's dog. While comparing the clinical score of day 1 to day 5 of individual groups, it was found that treatment administered in the group I to IV were highly significant. The remaining therapeutics protocol was same for all four groups. Different variations in the clinical signs in different dogs might be due to individual 
Table 1: Details of drug administered in various treatment groups

\begin{tabular}{|c|c|c|c|c|}
\hline Class & Group I & Group II & Group III & Group IV \\
\hline \multicolumn{5}{|c|}{ Treatments were given for five days } \\
\hline Antimicrobials & $\begin{array}{l}\text { Cefotaxim@25 } \\
\text { mg/kg BW/ Day } \\
\text { IV }\end{array}$ & $\begin{array}{l}\text { Metronidazole @ } 20 \mathrm{mg} / \mathrm{kg} \\
\mathrm{BW} / \text { Day. IV in two divide } \\
\text { doses }\end{array}$ & $\begin{array}{l}\text { Acyclovir @ } 20 \mathrm{mg} / \mathrm{kg} \\
\text { BW/ at every eight hours. } \\
\text { IV }\end{array}$ & $\begin{array}{l}\text { Cefotaxim@ } 25 \text { mg/kg BW/ Day. } \\
\text { IV+Acyclovir @ } 20 \text { mg/kg BW/ at } \\
\text { every eight hours IV }\end{array}$ \\
\hline $\begin{array}{l}\text { Gastrointestinal } \\
\text { protectants }\end{array}$ & \multicolumn{4}{|c|}{ Pentoprazole@1mg/kg BW/ Day IV OD } \\
\hline Antiemetics & \multicolumn{4}{|c|}{ Ondansetron@0.5 mg/kg BW IV TID } \\
\hline Fluid therapy Crystalloid & \multicolumn{4}{|c|}{ Replacement fluid $/ 24 \mathrm{hrs}$ as per $\%$ of Dehydration ${ }^{\mathrm{a}}$} \\
\hline Endotoxemic agent & \multicolumn{4}{|c|}{ Flunixin@1 mg/kg BW IV once only } \\
\hline $\begin{array}{l}\text { Supportive and Immune } \\
\text { modulator }\end{array}$ & \multicolumn{4}{|c|}{ Immuno $^{\mathrm{b}}+<5 \mathrm{~kg}: 1$ serving TID, $5-10 \mathrm{~kg}: 2$ serving TID } \\
\hline Haemostatic & \multicolumn{4}{|c|}{$\begin{array}{l}\text { Ethamcylate @ } 250-500 \text { mg (Total dose) IV BID in dogs where bloody diarrhea or melena was clinically } \\
\text { present. }\end{array}$} \\
\hline
\end{tabular}

$\%$ of Dehydration ${ }^{\mathrm{a}} \times \mathrm{BW}$ in $\mathrm{kg}=$ Liter of fluid required. Ringer lactate $(\mathrm{RL})$ followed by Dextrose Normal saline (DNS), Immuno + is a multivitamin commercially available product in spray form by Venttura Bioceuticals Private Limited, Mumbai, Maharashtra, India. The ScanVetParvo was obtained from M/S INTAS Pharmaceuticals Limited Matoda-382210, Ahmedabad, Gujarat, India.

Table 2: Various attributes for judging clinical conditions of parvo virus affected dogs.

\begin{tabular}{llllll}
\hline Score* & Attitude & Appetite & Vomiting & Feces & Temperature $\left({ }^{\circ} \mathbf{F}\right)$ \\
\hline 0 & Normal & Normal & Absent & Well formed or absent & Normal (100.4) \\
1 & $\begin{array}{l}\text { Mild to Moderate } \\
\text { depression }\end{array}$ & $\begin{array}{l}\text { Voluntarily eats small } \\
\text { amounts }\end{array}$ & Mild; once per 12 hrs & Soft or pasty feces & Mild increase (103.1) \\
2 & Severe depression & No interest in Food & $\begin{array}{l}\text { Moderate; 2-5 times } \\
\text { per 12 hrs }\end{array}$ & $\begin{array}{l}\text { Watery dirrrhea, non } \\
\text { bloody }\end{array}$ & Increase (104.0) \\
3 & Collapsed or & Not offered & Severe; 6 times per & Watery bloody dirrrhea & Severe increase (105.8) \\
\hline
\end{tabular}

host resistance, virulence of the viral agent and nutritional status of the individual dog (Banja et al., 2002). Diarrhea might be due to destruction and collapse of the germinal epithelium of the intestinal crypts by CPV and resulted as villous atrophy (Bastan et al., 2013). Dehydration was also one of the characteristic clinical sign in the present study due to large quantity of fluid losses from vomition and diarrhea. Similar observations were noted by Decaro and Buonavoglia (2012).

The reduction in haemoglobin values in almost all the groups on day 0 might be due to severe haemorrhagic enteritis (Sharma et al., 2005) stated that Canine parvo virus (CPV) damages the capillaries of the intestinal villi leading to loss of blood and resulted to reduced total erythrocyte levels. Further, the hemoglobin value was also reduced from day 0 to day 5 in group II, III and IV might be due to persistent fluid therapy administered to the dogs. The hemoglobin value was significantly lower on day 5 of group II in comparison with value on day 0 and healthy control could be due to poor control over gut sepsis resulted in constant bloody diarrhea which was also co-related with the clinical score of this group.

The higher PCV of all the groups on day 0 then healthy dogs might be due to effect of dehydration as haemoconcentration due to vomition and diarrhea as well as anorexia and reduced water intake due to effect of CPV infection (Vipankumar et al., 2014). After the 5 days of treatment, the PCV of group I(31.66 \pm 2.50$)$ significantly decreased but non significant variation observed on group III (37.99 \pm 3.47$)$ and IV (34.80 \pm 2.42$)$ suggestive of effective therapy administered in group III and IV resulted in restoration of dehydration and $\mathrm{PCV}$ reached to nearer that of the healthy dogs. The PCV decreased significantly in group II (29.31 \pm 1.59$)$ on day 5 might be due to either 
Table 3: Observed Clinical score of CPV affected dogs based on various attributes

\begin{tabular}{lllllll}
\hline Groups & Day 1 & Day 2 & Day 3 & Day 4 & Day 5 & P Value \\
\hline Group I & $2.29 \pm 0.29$ & $2.14 \pm 0.26$ & $1.57 \pm 0.20$ & $0.86 \pm 0.26$ & $0.29 \pm 0.18$ & $<0.01^{*}$ \\
Group II & $2.37 \pm 0.19$ & $2.18 \pm 0.34$ & $1.71 \pm 0.18$ & $1.0 \pm 0.31$ & $0.50 \pm 0.22$ & $<0.01^{*}$ \\
Group III & $2.57 \pm 0.20$ & $2.43 \pm 0.30$ & $1.86 \pm 0.34$ & $1.57 \pm 0.37$ & $0.33 \pm 0.22$ & $<0.01^{*}$ \\
Group IV & $2.43 \pm 0.20$ & $1.57 \pm 0.20$ & $0.86 \pm 0.26$ & $0.29 \pm 0.18$ & $0.0 \pm 0.0$ & $<0.01^{*}$ \\
\hline
\end{tabular}

$\mathrm{P}<0.05^{*}$ : Significant.

Table 4: Cost of treatment for CPV affected dog

\begin{tabular}{ll}
\hline Particulars & $\begin{array}{l}\text { Overall Treatment Cost } \\
\text { (Mean } \pm \text { SE) }\end{array}$ \\
\hline Group I & $1304.24 \pm 36.10$ \\
Group II & $983.58 \pm 87.34$ \\
Group III & $3469.71 \pm 937.67$ \\
Group IV & $3654.21 \pm 666.95$ \\
\hline
\end{tabular}

The f-ratio value is 5.91701. The $\mathrm{p}$-value is .003591 . The result is significant at $\mathrm{p}<0.05$.

Table 5: Comparative blood biochemistry of healthy vs CPV affected dogs

\begin{tabular}{|c|c|c|c|c|c|c|c|c|c|}
\hline \multirow[b]{2}{*}{ Groups } & \multirow[b]{2}{*}{ Treatment } & \multicolumn{2}{|c|}{ Haemoglobin (g/dl) } & \multicolumn{2}{|l|}{ PCV (\%) } & \multicolumn{2}{|l|}{ TEC(x10 $\% / \mu \mathrm{l})$} & \multicolumn{2}{|l|}{ Glucose (mg/dl) } \\
\hline & & Mean $\pm \mathbf{S E}$ & $\begin{array}{l}\text { Healthy } \\
\text { Control }\end{array}$ & Mean $\pm \mathbf{S E}$ & $\begin{array}{l}\text { Healthy } \\
\text { Control }\end{array}$ & Mean $\pm \mathbf{S E}$ & $\begin{array}{l}\text { Healthy } \\
\text { Control }\end{array}$ & $\operatorname{Mean} \pm \mathbf{S E}$ & $\begin{array}{l}\text { Healthy } \\
\text { Control }\end{array}$ \\
\hline \multirow[t]{2}{*}{ Group I } & Day 0 & $8.17^{\mathrm{b}} \pm 1.12^{*}$ & \multirow{2}{*}{$\begin{array}{l}-11.43^{\mathrm{a}} \pm \\
0.32\end{array}$} & $38.37^{\mathrm{a}} \pm 3.49^{*}$ & \multirow{2}{*}{$\begin{array}{l}33.71^{\mathrm{b}} \pm \\
0.75\end{array}$} & $4.54^{\mathrm{a}} \pm 0.62$ & \multirow{2}{*}{$\begin{array}{l}5.63^{\mathrm{a}} \pm \\
0.16\end{array}$} & $56.63^{\mathrm{c}} \pm 3.32^{* *}$ & \multirow{2}{*}{$\begin{array}{l}-71.26^{b} \pm \\
2.06\end{array}$} \\
\hline & Day 5 & $8.30^{\mathrm{b}} \pm 0.72^{*}$ & & $31.66^{\mathrm{c}} \pm 2.50^{*}$ & & $4.51^{\mathrm{b}} \pm 0.43^{*}$ & & $91.97^{\mathrm{a}} \pm 2.89^{* *}$ & \\
\hline \multirow[t]{2}{*}{ Group II } & Day 0 & $9.63^{b} \pm 0.49^{* *}$ & \multirow{2}{*}{$\begin{array}{l}-11.43^{a} \pm \\
0.32\end{array}$} & $36.15^{\mathrm{a}} \pm 1.83^{*}$ & \multirow{2}{*}{$\begin{array}{l}-33.71^{\mathrm{b}} \pm \\
0.75\end{array}$} & $5.22^{\mathrm{ab}} \pm 0.37$ & \multirow{2}{*}{$\begin{array}{l}-5.63^{\mathrm{a}} \pm \\
0.16\end{array}$} & $48.82^{b} \pm 5.23^{* *}$ & \multirow{2}{*}{$\begin{array}{l}-71.26^{\mathrm{a}} \pm \\
2.06\end{array}$} \\
\hline & Day 5 & $7.34^{c} \pm 0.46^{* *}$ & & $\begin{array}{l}29.31^{\mathrm{c}} \pm \\
1.59^{* *}\end{array}$ & & $4.49^{b} \pm 0.31^{*}$ & & $82.49^{a} \pm 3.39$ & \\
\hline \multirow[t]{2}{*}{ Group III } & Day 0 & $9.73^{\mathrm{a}} \pm 0.87$ & \multirow{2}{*}{$\begin{array}{l}11.43^{\mathrm{a}} \pm \\
0.32\end{array}$} & $41.23^{\mathrm{a}} \pm 2.65^{*}$ & \multirow{2}{*}{$\begin{array}{l}-33.71^{\mathrm{b}} \pm \\
0.75\end{array}$} & $5.56^{\mathrm{a}} \pm 0.548$ & \multirow{2}{*}{$\begin{array}{l}5.63^{\mathrm{a}} \pm \\
0.16\end{array}$} & $51.75^{\mathrm{c}} \pm 2.80^{* *}$ & \multirow{2}{*}{$\begin{array}{l}71.26^{\mathrm{b}} \pm \\
2.06\end{array}$} \\
\hline & Day 5 & $9.20^{\mathrm{c}} \pm 0.79^{*}$ & & $37.99^{\mathrm{b}} \pm 3.47$ & & $5.48^{\mathrm{a}} \pm 0.61$ & & $105.52^{\mathrm{a}} \pm 3.06^{* *}$ & \\
\hline \multirow[t]{2}{*}{ Group IV } & Day 0 & $9.36^{\mathrm{b}} \pm 0.67 *$ & \multirow{2}{*}{$\begin{array}{l}11.43^{\mathrm{a}} \pm \\
0.32\end{array}$} & $39.66^{\mathrm{a}} \pm 2.74^{*}$ & \multirow{2}{*}{$\begin{array}{l}33.71^{\mathrm{b}} \pm \\
0.75\end{array}$} & $5.67^{\mathrm{ab}} \pm 0.60$ & \multirow{2}{*}{$\begin{array}{l}5.63^{\mathrm{a}} \pm \\
0.16\end{array}$} & $67.86^{b} \pm 11.57$ & \multirow{2}{*}{$\begin{array}{l}-71.26^{\mathrm{b}} \pm \\
2.06\end{array}$} \\
\hline & Day 5 & $8.93^{c} \pm 0.88^{*}$ & & $34.80^{\mathrm{b}} \pm 2.42$ & & $4.86^{\mathrm{a}} \pm 0.57$ & & $98.03^{\mathrm{a}} \pm 4.82^{* *}$ & \\
\hline
\end{tabular}

$\mathrm{P}<0.05^{*}$ : Significant, $\mathrm{P}<0.01 * *$ : Highly Significant and $\mathrm{P}>0.05$ : Non - Significant.

Note: Same alphabet showing no significant difference and different alphabet were significantly differed from each other.

persistent fluid therapy to cope up the daily fluid loss or intestinal bleeding. 
Table 6: Group wise TLC and DLC values of CPV affected dogs

\begin{tabular}{|c|c|c|c|c|c|c|c|c|c|c|c|}
\hline \multirow[b]{2}{*}{ Groups } & \multirow[b]{2}{*}{ Treatment } & \multicolumn{2}{|l|}{$\operatorname{TLC}(/ \mu \mathrm{I})$} & \multicolumn{2}{|c|}{ Neutrophils (\%) } & \multicolumn{2}{|c|}{ Lymphocyte (\%) } & \multicolumn{2}{|c|}{ Eosinophils (\%) } & \multicolumn{2}{|c|}{ Monocytes (\%) } \\
\hline & & Mean \pm SE & Control & $\begin{array}{l}\text { Mean } \pm \\
\text { SE }\end{array}$ & Control & $\begin{array}{l}\text { Mean } \pm \\
\text { SE }\end{array}$ & Control & $\begin{array}{l}\text { Mean } \pm \\
\text { SE }\end{array}$ & Control & $\begin{array}{l}\text { Mean } \pm \\
\text { SE }\end{array}$ & Control \\
\hline \multirow[t]{3}{*}{ Group I } & Day 0 & $3614.29^{b} \pm$ & \multirow{3}{*}{$\begin{array}{l}9185.71^{\mathrm{a}} \pm \\
-311.24\end{array}$} & $69.47^{\mathrm{a}} \pm$ & \multirow{3}{*}{$\begin{array}{l}58.57^{\mathrm{ab}} \pm \\
2.93\end{array}$} & $24.60^{\mathrm{a}} \pm$ & \multirow{3}{*}{$\begin{array}{l}29^{\mathrm{a}} .00 \pm \\
1.31\end{array}$} & $2.86^{\mathrm{a}} \pm$ & \multirow{3}{*}{$-1.29^{b} .18$} & $2.57^{\mathrm{a}} \pm$ & \multirow{3}{*}{$\begin{array}{l}1.14^{b} \pm \\
0.26\end{array}$} \\
\hline & & $748.47 * *$ & & 4.33 & & 4.01 & & $0.51 * *$ & & $0.30^{* *}$ & \\
\hline & Day 5 & $\begin{array}{l}8180.00^{\mathrm{a}} \pm \\
460.04\end{array}$ & & $\begin{array}{l}54.27^{b} \pm \\
4.53\end{array}$ & & $\begin{array}{l}25.19^{\mathrm{a}} \pm \\
2.68\end{array}$ & & $\begin{array}{l}1.57^{b} \pm \\
0.20\end{array}$ & & $\begin{array}{l}1.43^{b} \pm \\
0.30\end{array}$ & \\
\hline \multirow[t]{3}{*}{ Group II } & Day 0 & $5200.00^{\mathrm{b}} \pm$ & \multirow{3}{*}{$\begin{array}{l}9185.71^{\mathrm{a}} \pm \\
-311.24\end{array}$} & $66.71^{\mathrm{a}} \pm$ & \multirow{3}{*}{$\begin{array}{l}58.57^{\mathrm{a}} \pm \\
2.93\end{array}$} & $24.43^{\mathrm{a}} \pm$ & \multirow{3}{*}{$\begin{array}{l}29.00^{\mathrm{a}} \pm \\
1.31\end{array}$} & $1.23^{\mathrm{a}} \pm$ & & $1.43^{\mathrm{a}} \pm$ & \multirow{3}{*}{$\begin{array}{l}1.14^{\mathrm{a}} \pm \\
-0.26\end{array}$} \\
\hline & & $1414.89 *$ & & \pm 5.33 & & 4.44 & & 0.18 & $1.29^{\mathrm{a}} \pm$ & 0.20 & \\
\hline & Day 5 & $\begin{array}{l}6042.86^{\mathrm{a}} \pm \\
1708.36\end{array}$ & & $\begin{array}{l}57.14^{\mathrm{a}} \pm \\
5.85\end{array}$ & & $\begin{array}{l}21.71^{\mathrm{b}} \\
\pm 1.95^{* *}\end{array}$ & & $\begin{array}{l}1.14^{\mathrm{a}} \pm \\
0.14\end{array}$ & 0.18 & $\begin{array}{l}1.29^{\mathrm{a}} \pm \\
0.18\end{array}$ & \\
\hline \multirow[t]{4}{*}{ Group III } & Day 0 & $5271.43^{b} \pm$ & \multirow{4}{*}{$\begin{array}{l}9185.71^{\mathrm{a}} \pm \\
-311.24\end{array}$} & $73.06^{\mathrm{a}} \pm$ & \multirow{4}{*}{$\begin{array}{l}58.57^{\mathrm{b}} \pm \\
-2.93\end{array}$} & $22.23^{\mathrm{ab}}$ & \multirow{4}{*}{$\begin{array}{l}29.00^{\mathrm{a}} \pm \\
-1.31\end{array}$} & $2.71^{\mathrm{a}} \pm$ & \multirow{4}{*}{ 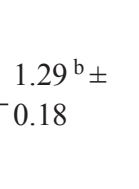 } & $1.71^{\mathrm{a}}$ & \multirow{4}{*}{$\begin{array}{l}1.14^{\mathrm{a}} \pm \\
-0.26\end{array}$} \\
\hline & & $980.212 * *$ & & $\pm 5.45^{*}$ & & \pm 5.83 & & $0.28 * *$ & & \pm 0.42 & \\
\hline & Day 5 & $3785.71^{\mathrm{c}} \pm$ & & $72.74^{\mathrm{a}} \pm$ & & $18.71^{\mathrm{b}} \pm$ & & $2.57^{\mathrm{a}}$ & & $1.43^{\mathrm{a}} \pm$ & \\
\hline & & $647.13 * *$ & & $3.30 *$ & & $2.68 * *$ & & $\pm 0.30 * *$ & & 0.20 & \\
\hline \multirow[t]{3}{*}{ Group IV } & Day 0 & $4642.86^{b} \pm$ & \multirow{3}{*}{$\begin{array}{l}9185.71^{\mathrm{a}} \pm \\
311.24\end{array}$} & $75.69^{a}$ & \multirow{3}{*}{$\begin{array}{l}58.57^{\mathrm{b}} \pm \\
2.93\end{array}$} & $22.46^{\mathrm{a}} \pm$ & \multirow{3}{*}{$\begin{array}{l}29.00^{\mathrm{a}} \pm \\
1.31\end{array}$} & $3.43^{\mathrm{a}} \pm$ & \multirow{3}{*}{$\begin{array}{l}1.29^{b} \pm \\
0.18\end{array}$} & $2.43^{a} \pm$ & \multirow{3}{*}{$\begin{array}{l}1.14^{b} \pm \\
0.26\end{array}$} \\
\hline & & $443.93 * *$ & & $\pm \pm 3.48 * *$ & & 5.70 & & $0.37 * *$ & & $0.37 *$ & \\
\hline & Day 5 & $\begin{array}{l}8171.43^{a} \pm \\
351.67\end{array}$ & & $\begin{array}{l}59.76^{\mathrm{b}} \\
\pm 1.87\end{array}$ & & $\begin{array}{l}26.56^{\mathrm{a}} \pm \\
2.23\end{array}$ & & $\begin{array}{l}2.43^{\mathrm{a}} \pm \\
0.43^{* *}\end{array}$ & & $\begin{array}{l}1.57^{\mathrm{b}} \pm \\
0.20\end{array}$ & \\
\hline
\end{tabular}

$\mathrm{P}<0.05^{*}$ : Significant, $\mathrm{P}<0.01^{* *}$ : Highly Significant and $\mathrm{P}>0.05$ : Non Significant

Note: Same alphabet showing no significant difference and different alphabet were significantly differed from each other.

Leucopenia can be associated with infection of viral origin that destroys actively dividing blast cells of bone marrow. After viral infections, decreased production and cell destruction result in leucopenia. (Brar et al., 2014). The TLC of all the groups on day 0 could be considered as leucopenia which may be due to the Canine Parvo Virus infection. After five days of continuous treatment, the mean TLC of group I, II and group IV showed non significant variation compared to healthy control groups. It was suggestive of improvement in immune status of particular groups due to antibiotic treatment administered in particular groups which contributed to enhance the ability to combat against infection. However, total leukocyte count of group III $(3785.71 \pm 647.13)$ on day 5 was significantly lower $(\mathrm{P}<0.01)$ than that of healthy control and suggestive of marked leucopenia. The leucopenia at day 5 was seen in group III could be due to use of acyclovir alone and none of the antibiotic was included in therapy.

The hypoglycemia was also reported by Bhat et al. (2013). The lower value of group I-IV on day 0 might be due to inappetence or anorexia (Coles, 1986) complemented by malabsorption from intestine and marginal increasing value of day 5 might be due to improvement in appetite following treatment and massive fluid therapy with dextrose normal saline as the part of all therapeutics groups.

Moreover, it was observed that the Immuno + was very effective in delivering immunomodulator agent as it was available in spray from, hence, easy to administer on tongue in puppies compare to other commercially available products.

\section{CONCLUSION}

Hence, it could be concluded that all the treatments administered were efficient against CPV infections as clinical score came to 0 at end of fifth day but clinical recovery and returning to normal physiological signs was earlier in group IV followed by group I in comparison with other treatment groups. While looking to the overall costing for treatment, group IV expenses are approximately 2.80 times higher than Group I. Nevertheless, survivability score was 100 percentages as well as clinical score was 
also return to normal at the end of fifth day in both groups. Therefore, it can be stated that treatment administered in group I was more economical than group IV while treatment administered in group IV was shown early recovery from clinical conditions than group I.

\section{ACKNOWLEDGEMENTS}

The authors are thankful to the Dr. J.N. Mistry, Professor and Head, Teaching Veterinary Clinical Complex, Veterinary Clinical Complex for providing facilities for conducting clinical studies.

\section{REFERENCES}

Banja, B.K., Sahoo, N., Das, P.K. and Ray, S.K. 2002. Clinicotherapeutic aspects of gastroenteritis in dogs. Indian Vet. J., 79: 837-840.

Bastan, I., Kurtede, A. and Ozen, D. 2013. Prognostic usefulness of some parameters in dogs with canine parvovirus. Ankara Univ. Vet. Fak. Derg., 60: 53-58.

Bhat, A.A., Wadhwa, D.R., Singh, S.P. and Singh, I. 2013. Haematological and biochemical analysis in canine enteritis. Vet. World, 6(7): 380-383.

Brar, R.S., Sandhu, H.S. and Singh, A. 2014. Veterinary Clinical Diagnosis by Laboratory Methods. Kalyani Publishers, Ludhiana, India, pp. 143-146.

Coles, E.H. 1986. Veterinary Clinical Pathology. (4 ${ }^{\text {th }}$ Edition), W.B Saunders Company, Philadelphia, pp. 80-96.

Decaro, N. and Buonavoglia, C. 2012. Canine parvovirus-A review of epidemiological and diagnostic aspects, with emphasis on type 2c. Vet. Microbiol., 155: 1-12.
Mohr, A.J., Leisewitz, A.L., Jacobson, L.S., Steiner, J.M. and Ruaux, C.G. 2003. Effect of early enteral nutrition on intestinal permeability, intestinal protein loss, and outcome in dogs with severe parvoviral enteritis. J. Vet. Intern. Med., 17(6): 791-798.

Nandi S. and Manoj Kumar. 2010. Canine Parvovirus: Current Perspective, Indian. J. Virol., 21(1): 31-44.

Otto, C.M. 2010. Treating Parvovirus (Proceedings). Retrieved from http://veterinarycalendar.dvm360. com/ treatingparvovirusproceedings

Pandya, S.M., Sharma, K.K., Kalyani, I.H. and Sakhare, P.S. 2017. Study on Host Predisposing Factors and Diagnostic Tests for Canine Parvovirus (CPV-2) Infection in Dogs. $J$. Anim. Res., 7(5): 897-902.

Sharma, B.M., Hazarika, G.C. and Chakravarty, P. 2005. Haematological profile in canine parvovirus infection. Indian. Vet. J., 82: 332-33.

Sharma, S., Dhar, P. and Sharma, M. 2019. Study of different risk factors for Canine Parvovirus infection by haemagglutination assay. J. Anim. Res., 9(5): 735-739.

Snecodor, G.W. and Cochran, W.G. 1990. Statistical Methods. Indian edition (Revised). Oxford and IBH Publishing Co. New Delhi, 345.

Vipankumar, Hei. G., Parveen Kumar and Sharma, H. 2014. Therapeutic management and haemato- biochemical evaluation of canine parvo virus infection. Ann. Vet. Anim. Sci., 3: 151-153. 